No. $1 / 2021$
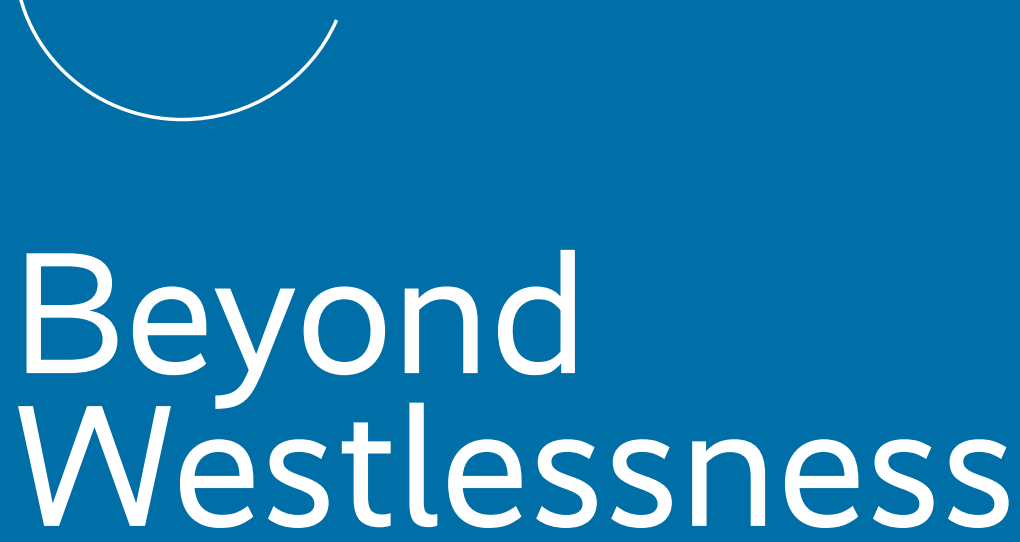

A Readout From the Munich Security Conference Special Edition 2021

Munich Security Brief

February 2021 
Author

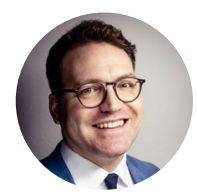

Dr. Tobias Bunde is Director of Research \& Policy at the Munich Security Conference and Postdoctoral Researcher at the Centre for International Security at the Hertie School in Berlin. 


\title{
Summary
}

\begin{abstract}
World leaders, including new US President Joe Biden, used the Munich Security Conference Special Edition, broadcast live from Munich on February 19, 2021, to send a strong signal of transatlantic renewal and to present their ideas on how to deal with some of the most pressing issues, including the Covid-19 pandemic and climate change.
\end{abstract}

The MSC Special Edition, a three-hour program featuring, among others, heads of state and government from Germany, France, the United Kingdom, and the United States, as well as the heads of the EU, NATO, the WHO, and the UN, took place on what was supposed to be the opening day of the $\mathrm{Mu}-$ nich Security Conference 2021, postponed due to the pandemic. Broadcast from the Hotel Bayerischer Hof, the traditional venue of the MSC, it provided key leaders an opportunity to demonstrate their shared commitment to renew, rebuild, and reform the transatlantic partnership and multilateral cooperation and move beyond a state of "Westlessness." President Biden's message to America's allies - "America is back, the transatlantic alliance is back" - was met with relief.

Yet, the speakers at the MSC Special Edition were clear that the world's liberal democracies find themselves at an important juncture: Many put a particular emphasis on the challenges facing open societies from within and from without and called for an effort to renew cooperation among democracies in the systemic competition with authoritarian great powers. While the event demonstrated a new transatlantic momentum, it was only the starting point for a true renewal of the partnership that still lies at the core of West. The discussions showed that much work remains to translate a shared commitment to developing a common strategy on major issues into an actionable program that can overcome transatlantic differences and deliver results. The MSC will try to support this process with a series of events, the "Road to Munich 2021" campaign, leading up to an in-person conference, which will take place as soon as conditions permit. 


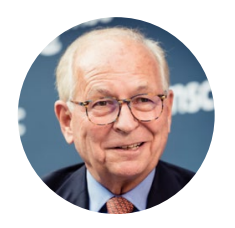

"Let us hope that the discussion we are starting in Munich this weekend will deliver the necessary impulses to go forward together, and in shared transatlantic responsibility."

Wolfgang Ischinger, Chairman of the Munich Security Conference, Munich, February 19, 2021

\section{Beyond Westlessness}

From its very beginnings, the Munich Security Conference, once known as Wehrkundetagung, has had a reputation as a decidedly transatlantic forum, where defense officials, parliamentarians, and intellectuals discuss Western strategy. While, over the years, its list of participants and speakers has become far more diverse and global, fostering transatlantic cooperation is still at the core of its mission. Thus, when the MSC chose "Westlessness" to be its motto for its annual conference in 2020, some critics regarded this choice as some sort of heresy. For others, however, the term, coined by our Munich Security Report 2020, adequately captured the zeitgeist of the West's identity crisis: Not only was the world becoming less Western, the West itself was becoming less Western, too. ${ }^{3}$

Unfortunately, the developments over the past year have vindicated our diagnosis. ${ }^{4}$ The storming of the US Capitol, incited by the outgoing President of the United States who refused to acknowledge the outcome of the presidential elections, was only the most emblematic symbol of the threat against a liberal-democratic set of norms that were once taken for granted, but turned out to be more fragile than most could have imagined. Likewise, several European countries have seen the rise of illiberal political forces and some have been suffering from ever more systematic attempts to undermine the rule of law. Moreover, the group of countries that see themselves as the cradle of the Enlightenment is witnessing the rise of conspiracy theories and a modern anti-scientism, only exacerbated by the Covid-19 pandemic. For some critics, the "incompetent responses of Western governments" during the pandemic are further proof of their relative decline. ${ }^{5}$ For others, the pandemic is, at least, a wake-up call. ${ }^{6}$

Apart from domestic problems, Western countries have also failed to maintain effective cooperation. When the financial and economic crisis hit more than a decade ago, transatlantic leaders were quick to closely coordinate their fiscal and political measures. But when the pandemic began to spread across the globe last year, such coordination was almost completely absent. As Ian Bremmer put it at an MSC Digital Conversation in April 2020, "you could not have a better example of 'Westlessness' than the response we are not seeing globally, from the US and Europe, to the largest crisis we have had since World War II." In Europe, too, national leaders in the beginning resorted to a "my country first" policy that only gave way to more solidarity after a while. ${ }^{8}$ 


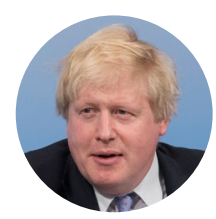

"So without wishing for a moment to downplay the challenges and dangers we face, in the teeth of a global pandemic, let me respectfully suggest that the gloom has been overdone and we are turning a corner, and the countries we call the 'West' are drawing together and combining their formidable strengths and expertise once again, immensely to everybody's benefit."

Boris Johnson, Prime Minister of the United Kingdom, London, February 19, 2021
But while the EU has managed to bring about an unprecedented aid package, European countries have spent much less time thinking about the people outside Europe's borders. While the pandemic could have driven home the message that no one is safe until everybody is safe, it seems to have strengthened nationalist approaches. Moreover, the weak performance of international attempts to cooperate in the crisis, supposed to demonstrate the added value of common efforts and solidarity, such as the European Union's joint procurement of vaccines, may have an adverse effect on the prospects for international cooperation.

But there is hope, too. As we wrote in the Munich Security Report last year, „Western countries, at least in theory, possess the necessary ideational, material, and institutional resources for a revitalization that will provide them with long-term advantages in a competitive environment."9 Most importantly, the election of Joe Biden as US president was widely heralded as an opportunity to reinvigorate the West. While certainly not sufficient to address all global challenges, transatlantic cooperation still remains a necessary condition for effective collective action on the global level. Biden's election thus promised not only the renewal of the transatlantic partnership but also a recommitment to joint transatlantic approaches to tackle major global challenges - from the raging Covid-19 pandemic to climate change.

The Munich Security Conference 2021, traditionally held in February, would have offered a much needed opportunity for a renewal of the transatlantic partnership and international cooperation at this important juncture. Since the pandemic prevented the conference from going forward as planned, the MSC decided to host an MSC Special Edition focusing on the transatlantic relationship and some of its core challenges.

Broadcast live from the Hotel Bayerischer Hof in Munich on February 19, 2021, what was supposed to be the opening day of the Munich Security Conference 2021, it served as the kick-off event for a series of digital conversations and workshops - the "Road to Munich" - taking place between now and the (yet to be scheduled) in-person conference. The latter will, as usual, cover issues beyond the transatlantic relationship and feature more speakers and participants from the non-Western world. In contrast, the specific aim of the Special Edition was, in Ischinger's words, "to look beyond 'Westlessness" and to ask "for answers to pressing questions: How can we rebuild, renew and reform the transatlantic partnership? And how can we join forces to tackle global challenges?”10 


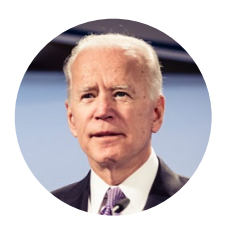

"I speak today as President of the United States at the very start of my administration, and I'm sending a clear message to the world: America is back. The transatlantic alliance is back. And we are not looking backward; we are looking forward, together."

Joe Biden, President of the United States of America, Washington, DC, February 19, 2021
The line-up of speakers at the MSC Special Edition - including heads of state and government of France, Germany, the United Kingdom, and the United States, as well as the heads of the EU, NATO, the UN, and the WHO - testified to the willingness of world leaders to renew multilateral cooperation and to move beyond Westlessness.

\section{Renewing Transatlantic Relations: "America Is Back”}

Since its inauguration, the Biden administration has taken a series of decisions underlining the renewed commitment to multilateral cooperation and an international agenda of "building back better." In the weeks before the MSC Special Edition, the United States announced an extension of the New START treaty, limiting strategic nuclear arsenals of the US and the Russian Federation, its willingness to enter into negotiations with the $\mathrm{P} 5+1$ about the future of the JCPOA, a return to the Paris Climate Agreement and the World Health Organization and its commitment to contribute to the vaccine pillar of the Access to Covid-19 Tools (ACT) Accelerator, COVAX. ${ }^{11}$

The fact that President Joe Biden chose the Munich Security Conference as the venue for his first major address to a foreign audience was widely seen as a symbolic message to Europe. After all, Biden, a long-time participant in the Munich Security Conference who first attended it as a young senator in 1980, was the first sitting president to address the conference - even if only virtually. Two years ago at the Munich Security Conference, in the midst of harsh transatlantic disagreements that translated into a cold atmosphere in Munich, Biden had taken to the stage as a private citizen, trying to convince the European audience that it must not count America out: "We will be back!"12

Addressing his European allies from the East Room in the White House, Biden referred to this speech again: "I'm a man of my word. America is back." In a stark contrast to his predecessor, Biden referred to the transatlantic alliance as "the strong foundation on which our collective security and our shared prosperity are built.” Echoing his previous speeches in Munich, Biden emphasized that the US-European partnership "is and must remain the cornerstone of all that we hope to accomplish in the 21st century, just as we did in the 20th century." The US president was also clear in his support for collective defense, referring to NATO's Article 5 as a "guarantee" and the US commitment to it as "our unshakable vow." Pointing to European support for the United States in the aftermath of the terrorist attacks on New York 


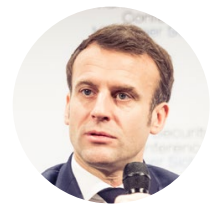

"I do believe in NATO.

I believe NATO needs a new political momentum and clarification of its strategic concept. And NATO needs a more political approach."

Emmanuel Macron, President of the French Republic, Paris, February 19, 2021 and Washington, DC almost 20 years ago and in the fight against ISIS, Biden stressed that the United States was "determined to reengage with Europe, to consult with you, to earn back our position of trusted leadership."

In her response to Biden, German Chancellor Angela Merkel welcomed the first announcements and decisions of the new administration as "important steps toward more multilateral cooperation.” Turning to her own country, Merkel argued that Germany had to take action outside its comfort zone. ${ }^{13}$ She reiterated her commitment to reaching NATO's two-percent goal, pointing out that Germany had moved from spending 1.1 percent of GDP on defense in 2014 to roughly 1.5 percent in 2021. Merkel also underlined Germany's contributions to international peace and stability operations and announced that Germany would be ready to stay in Afghanistan longer to prevent the country from descending into chaos once again.

French President Emmanuel Macron made headlines just before the MSC Special Edition, as he argued in an interview that "nobody can tell me that today's NATO is a structure that, in its foundations, is still pertinent. It was founded to face down the Warsaw Pact. There is no more a Warsaw Pact." ${ }^{14}$ In his statement at the MSC Special Edition, Macron again called for a fundamental overhaul of NATO, insisting that "all I said last year remains valid," but also underlined that he believed in NATO. Pointing to the reflection group process, the French President called for the next step: a new Strategic Concept for NATO.

When Wolfgang Ischinger asked him to respond to the concerns that the concept of "strategic autonomy" had raised in the United States, Macron replied that in his view European "strategic autonomy" was not only compatible with the Alliance but would "make NATO even stronger than before." Arguing that the United States was now a Pacific power, mainly focusing on China, Macron said that "we need more Europe to deal with our neighborhood." If the Europeans depended too much on the US in Europe, they would risk being without protection. "In previous decades the US was much more focused on Europe," Macron stressed, This would require Europe to do more for its own security in its neighborhood: "It is time for us to take much more of the burden of our own protection."

Jens Stoltenberg, who had been praised for his steady hand guiding the Alliance through the tumultuous Trump presidency, ${ }^{15}$ spoke of a "historic op- 
portunity to build a stronger Alliance" and to work together "in strategic solidarity," after years with "competing visions of the transatlantic relations." Stoltenberg presented some elements of a new transatlantic agenda - NATO 2030 - ranging from the rise of China to disruptive technologies, climate change to the more familiar challenges posed by Russia and terrorism. Like Macron, Stoltenberg expressed his support for a new strategic concept "to chart a common course going forward.”

\section{Systemic Competition: Democracies vs. Autocracies?}

Many speakers stressed the importance of shared democratic values that had to be defended at home and abroad. Biden admitted that "in so many places, including in Europe and the United States, democratic progress is under assault." The central part of his speech dealt with what he called an "inflection point" between believers in autocracy and supporters of democracy. Calling on "our fellow democracies," Biden summoned the support for "our galvanizing mission": demonstrating that "democracies can still deliver for our people in this changed world" and "that our model isn't a relic of history, it's the single best way to revitalize the promise of our future." In a similar vein, Chancellor Merkel underlined the importance of delivering positive outcomes. It was up to democratic states, she said, "not just to talk about freedom, about values but also to bring about results.”

The political leaders addressing the conference, however, seemed to outline different visions for multilateral cooperation among democracies in the face of illiberal counterforces. ${ }^{16}$ Biden was clear, arguing that "we must prepare for a long-term strategic competition with China" and "meet the threat from Russia.” In a similar way, NATO Secretary General Jens Stoltenberg warned that the international rules-based order was "being challenged by authoritarian powers." According to him, "China and Russia are trying to re-write the rules of the road to benefit their own interests." Likewise, Charles Michel, President of the European Council, stressed the necessity of a strong transatlantic alliance "to defend he rules-based international order from the attacks of autocratic regimes, whether from Russia, China or Iran," whereas Johnson referred to "hostile states" and argued that "our democracies need to strengthen their capabilities to meet the rigours of a more competitive world."

Biden and Johnson both called for values-based cooperation among the "free world," not confined to specific geographical areas. ${ }^{17}$ Stoltenberg also 


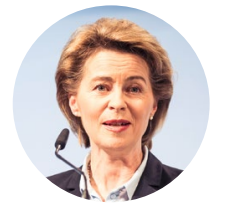

"A more and more assertive China has shown robust economic growth in 2020 - despite the pandemic. And a more and more defiant Russia continues to breach international rules at home and abroad - despite growing protests of its own citizens. It is up to us, the United States and Europe, to strengthen our cooperation again."

Ursula von der Leyen, President of the European Commission, Brussels, February 19, 2021 emphasized that "concerted action" was needed to "encourage others to play by the rules" and argued that "NATO should deepen our relationships with close partners, like Australia and Japan, and forge new ones around the world." While the core of Biden's speech was cooperation among democracies, he did not explicitly mention his proposal for a Summit for Democracy that he had made during the campaign..$^{18}$ Similarly, Johnson refrained from renewing his call for a D10, a grouping of the ten most important democracies, but emphasized the need to strengthen cooperation among "free countries - many of them located far beyond the geographical West". He noted that he had invited Australia, South Korea and India to attend the G7 Summit in Cornwall as guests. This would make it an informal D10 meeting.

Chancellor Merkel used a slightly different vocabulary and avoided to describe China and Russia as rivals or threats but rather called on the transatlantic partners to "develop common strategies" toward these two countries: "In recent years, China has gained more power on the international stage, and we as a transatlantic alliance and as democratic countries need to react to that," Merkel said. While she acknowledged that China was a "systemic competitor", she also stressed that "we need China for the solution of global problems."

Speaking about the challenge posed by Russia, the German chancellor unequivocally stated the Minsk process had not made any progress regarding the sovereignty and territorial integrity of Ukraine and accused Russia of repeatedly involving member states of the European Union in hybrid conflicts. Merkel called for a joint transatlantic Russia agenda "that, on the one hand, of course also makes cooperative offers, but on the other hand also clearly identifies the differences." In his intervention, Macron, in contrast, only briefly mentioned Russia, just advocating for dialogue, and referred to China only in passing, naming it as the major concern for the US.

\section{Meeting Global Challenges: “Competition Must Not Lock Out Cooperation"}

The general support for increased cooperation among the world's democracies notwithstanding, speakers at the MSC Special Edition made clear that this was not enough. UN Secretary General António Guterres emphasized how important it was that the West, after often being "at odds in the recent past," was united. Asked about the role of the US and Europe for the United Nations, he said that the West needed to be able to assert its principles but 


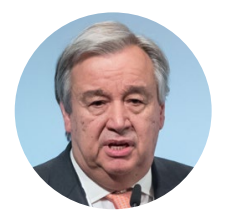

"We need to ease geopolitical tensions and enhance diplomacy for peace. We cannot solve the biggest problems when the biggest powers are at odds."

António Guterres, UN Secretary General, New York, February 19, 2021 also to engage others in a multipolar world. According to Guterres, the global pandemic had "x-rayed the world, exposing deep fissures and fragilities." The UN secretary general outlined the long list of global challenges, many of which Covid-19 has exacerbated, turning what was first seen as a health crises into what a recent Munich Security Report Special Edition called the "Polypandemic." 19

While Biden focused on revamping cooperation among democratic countries in the face of autocratic challengers in his speech, he underlined that the world was not all about great-power competition: "We cannot and must not return to the reflexive opposition and rigid blocks of the Cold War. Competition must not lock out cooperation on issues that affect us all." ${ }^{20}$ Unsurprisingly, the two most pertinent global challenges discussed at the MSC Special Edition were the Covid-19 pandemic and climate change.

Recognizing the real hope that vaccines will allow the international community to rein in the pandemic, Tedros Adhanom Ghebreyesus, the director general of the WHO, reminded the audience that the Covid-19 pandemic was an "uneven pandemic," affecting different countries and societies in different ways. Acknowledging the announcement the G7 countries made just hours before, Tedros called on governments to fully fund COVAX as well as "donate doses now." As the WHO director general made clear, this was the best way to fight the pandemic and prevent the virus from developing new mutants: "The longer it takes to suppress the virus everywhere, the more opportunity it has to change in ways that could make vaccines less effective an opportunity to mutate. We could end up back at square one.” Bill Gates, co-chair of the Bill \& Melinda Gates Foundation, underlined the importance of reducing "vaccine inequity," suggesting that the "delta of the vaccination levels of the rich countries to the developing countries" could be significantly reduced: "We have a chance to get that gap to be only six months." Gates, who had warned of the underestimated threat posed by a global pandemic at the MSC in $2017,{ }^{21}$ called it a tragedy that comparatively low-cost measures that would have been able to contain the pandemic had not been taken. Gates called for additional investments to be better prepared for the next pandemic. Pointing to the discussion at the virtual G7 meeting that took place just before the MSC Special Edition, Johnson called for the "collective defense against the next pathogen, just as we unite against military threats.”

In his speech, Guterres called for a "Global Vaccination Plan," making vaccines "available and affordable for everyone, everywhere," suggesting the 


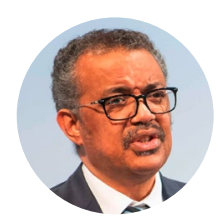

"Vaccine equity is not just the right thing to do, it's also the smart thing to do."

Tedros Adhanom Ghebreyesus, WHO Director-General, Geneva, February 19, 2021
G20 was the right forum to establish an "Emergency Task Force" to prepare such a plan that would aim to at least double global manufacturing capacity, made possible by the transfer of technology and sharing of licenses. In his statement, President Macron reiterated his proposal for the transatlantic partners to provide 6.5 million health workers with vaccines immediately. Otherwise, he warned, "our African friends will be pressured by their populations, and rightly so, to buy doses from the Chinese, the Russians or directly from laboratories" and "the power of the West, of Europeans and Americans, will be only a concept, and not a reality," underlining that even the fight against the pandemic takes places under the shadow of a broader systemic rivalry.

The speakers also discussed climate change, "the looming crisis behind Covid-19," as Ursula von der Leyen called it. On the day of the United States officially rejoinining the Paris Agreement, Biden pointed out that "we can no longer delay or do the bare minimum to address climate change," which he referred to as "a global, existential crisis." The MSC Special Edition made clear that, at least rhetorically, climate change has made it to the top of the agenda of the strategic community. At least, "it is front and center at the $\mathrm{Mu}$ nich Security Conference, which is exactly where it belongs today," as Biden's Special Envoy for Climate Change John Kerry said. Several speakers referred to climate change as a security issue. Unfortunately, as Bill Gates noted, there is, unlike in the case of the pandemic, no vaccine available that could stop climate change.

Notably, the speakers at the conference agreed that everyone needed to do their share. For example, NATO Secretary General Stoltenberg not only talked about climate change as a "threat multiplier," but also highlighted a specific contribution by NATO as a military alliance: "I believe NATO should set the gold standard on how to reduce the emissions of our militaries, contributing to the goal of Net Zero." In a passionate speech, John Kerry warned that the international community was now in the "decisive decade," as too much time had been wasted, and outlined an ambitious agenda for 2021, leading to the UN Climate Conference, COP26, in Glasgow in November.

\section{A Transatlantic Love Fest, Remaining Challenges, and the Road Ahead}

Had President Biden spoken in Munich, his speech would have been greeted with an audible sigh of relief in the audience. After several years of severe transatlantic tensions that often were palpable in conference hall, Biden's 



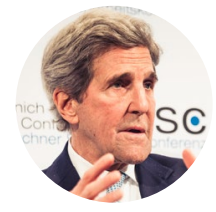

“What we do - or don't do - in the coming months and years will make all the difference. [...] We all need to develop not just a number, but a roadmap for how we will actually make the dramatic progress we need to make over the next ten years - and what we will specifically do to get to net-zero by no later than 2050."

John Kerry, Special Presidential Envoy for Climate, Washington, DC, February 19,2021 speech would clearly have been one of the most celebrated in the history of the conference. But even if Biden could only address a virtual audience, observers described the MSC Special Edition, which reached millions of viewers across the globe, as a "beautiful love fest of the old West." 22

If their aim was to transmit a powerful signal that the US and its European allies would now cooperate closely again, the speeches succeeded. All participants focused on shared values and at least underlined their willingness and readiness to closely coordinate their policies - whether on China, Iran, or Russia. In his statement at the end of the MSC Special Edition, Boris Johnson concluded that he sensed "a new resolve among our European friends and allies to come together and act again with unity and determination." But the speeches and discussions at the MSC Special Edition also highlighted the challenges that remain. As disagreements were only hinted at, the omissions or blind spots in the speeches were particularly telling.

On the one hand, this is not a tabula rasa moment from which the transatlantic partnership can just start anew. While it is not surprising that politicians wanted to look ahead, the most recent past will continue to haunt the transatlantic partnership. Biden, better suited than anyone to embody the return of the United States to its traditional role as Europe's trusted partner and ultimate security provider, admitted that a lot of trust had been destroyed and pushed all the right buttons to reassure his partners and allies. Yet, even he will only be able to repair the damage to a certain degree, as many in Europe fear the pendulum might swing back again. Europeans will certainly trust Joe Biden and his administration but will they have trust in the US body politic at large? As a new report by the Centre for European Reform summarizes these doubts: "Trumpism in some form is likely to endure, meaning that Europeans cannot be sure whether Biden's successors will be committed to European security." ${ }^{23}$ And while Boris Johnson underlined the "heroic endeavours of the world's scientists" fighting the pandemic, few people have forgotten the Brexit campaign and the denigration of "experts." The recent diplomatic row between the UK and European Commission, caused by Brussels' unfortunate announcement of potential export controls on vaccines crossing from the EU to Northern Ireland, illustrated the open wounds that remain after strenuous Brexit negotiations. Here, too, repair work is in order. In any case, blaming "pessimists" for talking the West into its own decline will not make the West's real problems disappear. ${ }^{24}$ Biden was clear: the community of liberal democracies is at an "inflection point." 


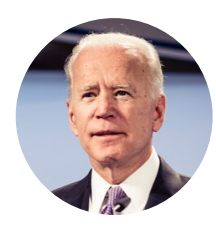

"You know, I hope our fellow democracies are going to join us in this vital work. Our partnerships have endured and grown through the years because they are rooted in the richness of our shared democratic values. They're not transactional. They're not extractive."

Joe Biden,

President of the United States of America, Washington, DC, February 19, 2021
On the other hand, the Europeans, by and large, missed an opportunity to lay out their own proposals for a new transatlantic bargain. Whereas Biden had a couple of specific announcements, including a halt of the US troop withdrawal from Germany, his European counterparts did not respond in kind. While it made sense, as many observers noted, not to tackle all divisive issues at this public session aiming at signalling a new beginning, some critics would have wished for some more specific proposals from the European side. Although Merkel noted in her remarks that Europe and Germany would have to be prepared to bite the bullet and do more in areas in which an extra effort was needed, it remained unclear what this would entail specifically. ${ }^{25}$

After Biden had stressed the United States' recommitment to European security, Macron emphasized the US reorientation to the Pacific Ocean, underlining what both partners would likely have to do in their parts of the world, but without offering a vision for what the two sides could do together. While most analysts agree that efforts to strengthen Europe's ability to act without US support are necessary and would benefit the Alliance, conflicting messages about NATO often raise unnecessary concerns even in well-meaning Washington circles. Finally, only Johnson was eager to offer something that could help the United States in what will likely be its focus region when he announced that the new British aircraft carrier would sail to the Indo-Pacific on her maiden deployment. ${ }^{26}$ Likely hinting at different perceptions of interests when it comes to China, as some commentators read it, ${ }^{27}$ Merkel also made clear that the interests of the transatlantic partners would not always be identical. How to translate a shared commitment to liberal-democratic values and the rules-based international order into a joint Western grand strategy on how to deal with China and Russia will remain a key challenge for the transatlantic community.

It has become almost a cliché in transatlantic foreign policy debates that a return to the status quo ante is not in the cards. Rather, as a recent policy brief by the European Council on Foreign Relations notes, it is time for transformation rather than restoration of the transatlantic partnership. ${ }^{28}$ Few doubt that the Europeans, in particular Germany, will have to do much more than before. ${ }^{29}$ They have to come up with their own proposals for transforming the transatlantic partnership, not just wait for Biden to return to a past that will not come back. If the speeches at the MSC Special Edition are an early indicator, there is considerable room for improvement in this respect. America is back, but where is Europe? 


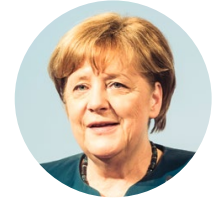

"[Our] interests will not always be identical. I have no illusions about that. We will also have to speak openly about our differences. But where our basic approach, our fundamental values, our convictions about democracy and its ability to deliver are concerned, we have a broad, solid common

foundation."

Angela Merkel, German Chancellor, Berlin, February 19, 2021
After all, the two points made here are related: President Biden can only do so much to repair the transatlantic partnership. It is in the Europeans' best interest to help him succeed with his agenda - both at home and abroad. In a way, Chancellor Merkel - quoting German author Erich Kästner to Biden: "there is nothing good unless you do it" - defined the ambition for the Europeans themselves. Germany, in particular, will have to show some flexibility and explore compromises concerning some of the obstacles toward a new transatlantic honeymoon, ranging from Nord Stream 2 to 5G, which were hardly mentioned at the MSC Special Edition. If the transatlantic partners prove unable to adapt to new challenges and make the transatlantic partnership work, they should not be surprised to face a new wave of nationalist and populist forces, putting to rest the idea of a liberal international order, in which liberal-democratic values can flourish.

As political scientist G. John Ikenberry writes, Woodrow Wilson's ambition to make the world safe for democracy, which has usually been understood as an "idealist appeal to spread democracy worldwide," can also "be read literally, as a plea for safety. Rather than an idealist appeal, it is a call to reform the postwar international order so as to allow Western liberal democracy to survive. ${ }^{30}$ Judging from the speeches in Munich, there is both a recognition that the liberal-democratic project is under increasing pressure and an understanding that the best way forward consists in a common transatlantic approach. After several years of transatlantic tensions, the shared commitment to seek a common Western grand strategy represent a promising first step. The next step will consist in translating the new transatlantic momentum into an actionable joint program that will deliver concrete results. For this to happen, transatlantic partners still have to develop a clearer understanding of each other's to-do lists and priorities.

The next months will offer various opportunities - including the Earth Summit in Washington, DC, a G7 Meeting in Cornwall, a NATO Summit in Brussels, the COP26 Meeting in Glasgow, and, hopefully soon, a regular Munich Security Conference - to table specific proposals and initiatives. Along the "Road to Munich 2021," the MSC will attempt to support the process of "renewing transatlantic relations and tackling global challenges" with a series of digital - and, hopefully soon, in-person - events, working groups, background briefings, and publications. As President Biden emphasized before leaving the video call: "So let's get working." ${ }^{31}$ The stakes are high. 


\section{Key Points}

(1) Speakers at the MSC Special Edition sent a strong signal of transatlantic renewal. In particular, President Biden's speech conveyed the message that the US was "back," ready and willing to closely work with Europe.

(2) Many speakers saw the world's liberal democracies at a crucial juncture: Facing tremendous challenges at home and abroad, Western countries will have to deliver on issues of concerns to their citizens and jointly address the challenge posed by authoritarian powers to prevent the rules-based order from unravelling.

(3) As transatlantic cooperation is necessary but often not sufficient, liberal democracies will have to work with all states on issues of global concern, ranging from ending the Covid-19 pandemic to containing climate change.

(4) Transatlantic partners need to use the momentum visible at the MSC Special Edition and turn it into an actionable program to deliver concrete results. The MSC will accompany and support this endeavor along the "Road to Munich 2021" campaign, a series of events leading up to the next in-person conference. 


\section{Endnotes}

1 If not noted otherwise, all quotes are from the Munich Security Conference Special Edition that took place on February 19,2021 . The recording can be accessed at the MSC website: https://securityconference.org/en/ msc-special-edition-2021/.

2 See, for example, Matthew Karnitschnig, "Trump Camp Finds No Appeasement at Munich," Politico, February 16,2020 , https://perma.cc/

C4GM-TGS5.

3 Tobias Bunde et al., "Munich Security Report 2020: Westlessness," Munich: Munich Security Conference, 2020, doi:10.47342/IAQX5691.

4 See also Jeremy Cliffe, "Westlessness: How Cracks Within NATO Signal a New Balance of Global Power," New Statesman, September 8, 2020, https://perma. cc/NM63-7RQX.

5 See, for example, Kishore Mahbubani, "The West's Incompetent Response to the Pandemic Will Hasten the Power-shift to the East," The Economist, April 20, 2020, https://perma.cc/ WD6W-X2YV.

6 See, for example, John Micklethwait and Adrian Wooldridge, The Wake Up Call: Why the Pandemic Has Exposed the Weakness of the West - and How to Fix It, London: Short Books, 2020.

7 Quoted in "A Transatlantic Conversation on the Geopolitical and Business Effects of COVID-19," Munich Security Conference, April 28, 2020, https://perma.cc/RD59-5Z8D.

8 See, for example, Wolfgang Ischinger and Boris Ruge, "Für Europa ist es eine Überlebensfrage," Zeit Online, April 2, 2020, https://perma.cc/8HF6-RDLQ.
9 Bunde et al., "Munich Security Report 2020," 22.

10 Wolfgang Ischinger, "Looking Beyond 'Westlessness'," Security Times, February 19, 2021, https://perma.cc/ GEU5-5CY2.

11 World Health Organization, "COVAX: Working for Global Equitable Access to COVID-19 Vaccines," Geneva: World Health Organization, https://perma. cc/9BH9-WRSH.

12 Biden's 2019 speech can be accessed at the MSC Media Library: https://securityconference.org/en/medialibrary/asset/statement-by-joseph-r-biden-jr-followed-by-qa-1400-16-02-2019/.

13 In her native German, Merkel used the expression "über den eigenen Schatten springen."

14 Quoted in Roula Khalaf, Ben Hall, and Victor Mallet, "Emmanuel Macron: 'For Me, the Key Is Multilateralism That Produces Results'," Financial Times, February 18, 2021, https://perma. cc/6KT8-MMK6.

15 Tom McTague and Yasmeen Serhan, "The Man Who Figured Out Trump," The Atlantic, December 4, 2019, https:// perma.cc/3GQT-HMPU.

16 For a helpful analysis of different pathways for Western multilateralism, see Thomas Wright, "Advancing Multilateralism in a Populist Age," Washington, DC: Brookings Institution, February 2021, https://perma.cc/2DY6-QHJX. Wright distinguishes between an incrementalist approach, trying to integrate China and other non-Western powers, an "alone in the jungle" approach which would mean the establishment of Europe as a third pole between the US and China, and a "reinvigorating the free world" approach whereby the US and Europe would work together to defend open societies against authoritarian 
challenges. Even if the brief speeches in Munich only gave a glimpse into the strategic thinking in Western capitals, they demonstrated that not everyone would be in the same camp.

17 The debate reminds of the discussions about a Global NATO or a Concert of Democracies that took place in the late 2000s, which was largely about two different strands of liberal internationalism - a universal one and an exclusive one. See Tobias Bunde and Timo Noetzel, "Unavoidable Tensions: The Liberal Path to Global NATO," Contemporary Security Policy 31:2 (2010), 295-318, doi:1 $0.1080 / 13523260.2010 .491380$. These different interpretations of liberal order building can be seen in the contemporary Western debate on how to deal with China (and Russia).

18 Joseph R. Biden, "Why America Must Lead Again: Rescuing U.S. Foreign Policy After Trump," Foreign Affairs 99:2 (2020), 64-76, https://perma.cc/D9MXNMPT, 67. "During my first year in office, the United States will organize and host a global Summit for Democracy to renew the spirit and shared purpose of the nations of the free world. It will bring together the world's democracies to strengthen our democratic institutions, honestly confront nations that are backsliding, and forge a common agenda."

19 Sophie Eisentraut et al., "Polypandemic: Special Edition of the Munich Security Report," Munich: Munich Security Conference, November 2020, doi:10.47342/CJAO3231.

20 Johnson echoed this statement: "We do not wish to live in a world of unchecked rivalry or decoupling or obstacles to sensible cooperation and global economic growth."

21 Bill Gates, "Speech at the Munich
Security Conference 2017,“ Munich, February 17, 2017, https://perma.cc/U4ZKJZZQ.

22 Claus Kleber, "ZDF heute journal," ZDF, February 19, 2021, https://perma. cc/7F7A-96RQ.

23 Sophia Besch and Luigi Scazzieri, "European Strategic Autonomy and a New Transatlantic Bargain,” London, Brussels, Berlin: Centre for European Reform, December 11, 2020, https://perma.cc/CGD7-ACWB.

24 In his statement, Johnson complained about "the industry of pessimism [that] has thrived recently, perhaps even in Munich.”

25 As pointed out by many commentators, Chancellor Merkel's response to Biden only offered very broad proposals. According to Tina Hassel, for instance, the Chancellor just reiterated what Germany was already doing, although knowing quite well that this would not be enough. See Tina Hassel, "Die Meinung von Tina Hassel, WDR, zu den transatlantischen Beziehungen,” ARD, February 19, 2021, https://perma.cc/ M7DV-KELD.

26 Johnson did not fail to mention that the deployment of HMS Queen Elizabeth took place in close cooperation with the US: "On her flight deck will be a squadron of F35 jets from the US Marine Corps; among her escorts will be an American destroyer, showing how the British and American armed forces can operate hand-in-glove - or plane-onflightdeck - anywhere in the world.” 27 David E. Sanger, Steven Erlanger and Roger Cohen, "Biden Tells Allies 'America Is Back,' but Macron and Merkel Push Back," The New York Times, February 19, 2021, https://perma.cc/R7JR-D6ET. 28 Julien Barnes-Dacey et al., "A New Transatlantic Bargain: An Action Plan 
for Transformation, Not Restoration," London/Berlin: European Council on Foreign Relations, Policy Brief, November 2020, https://perma.cc/EKT5-VD6K. 29 Our recent Munich Security Report Special Edition published in October 2020 provided an in-depth assessment of German foreign and security policy. See Tobias Bunde et al., "Zeitenwende | Wendezeiten: Special Edition of the Munich Security Report,"

https://doi.org/10.47342/SBID8214

30 G. John Ikenberry, A World Safe for

Democracy: Liberal Internationalism

and the Crises of Global Order, New Haven: Yale University Press, 2020, 1.

31 Quite symbolically, President Biden, according to the transcript published by the White House, was immediately confronted with a reporter's questions about a domestic challenge, the situation in Texas. See Joseph R. Biden, "Remarks by President Biden at the 2021 Virtual Munich Security Conference,” Washington, DC, February 19, 2021, https://perma.cc/WRV5-9ZEM. 


\title{
Image Sources
}

\author{
MSC/Hennemuth \\ P. 12 \\ MSC/Koch \\ P. 6 \\ MSC/Mueller \\ P. 22 \\ MSC/Oellermann \\ P. 11
}

All other images: MSC/Kuhlmann 


\section{Editorial Board}

Ambassador Wolfgang Ischinger, Ambassador Boris Ruge, Dr. Benedikt Franke

\section{Author}

Dr. Tobias Bunde

Managing Editor

Laura Hartmann

Layout

Felix Kirner

\section{Design}

MetaDesign

Stiftung Münchner Sicherheitskonferenz gGmbH

Karolinenplatz 3

80333 Munich

www.securityconference.org

research@securityconference.org

Visit our app and social media channels: www.linktr.ee/MunSecConf

DOI: https://doi.org/10.47342/NLUJ4791

Please cite as: Tobias Bunde, Beyond Westlessness: A Readout From the Munich Security Conference Special Edition 2021 (Munich Security Brief, February 2021), Munich: Munich Security Conference, https://doi.org/10.47342/NLUJ4791.

ISSN (Online): 2702-6574 


\section{About the Munich Security Conference (MSC)}

The Munich Security Conference is the world's leading forum for debating international security policy. In addition to its annual flagship conference, the MSC regularly convenes high-profile events around the world. The MSC publishes the annual Munich Security Report and other formats on specific security issues.

\section{The Munich Security Briefs}

With its Munich Security Briefs, the MSC aims at contributing to ongoing debates on a particular issue within the broad field of international security. A much more concise format than the Munich Security Report, the briefs are meant to provide an overview of an issue or a read-out of a particular MSC event as well as a succinct analysis of its policy implications and strategic consequences. They generally express the opinion of their author(s) rather than any position of the Munich Security Conference. 